\title{
Thrips species (Insecta: Thysanoptera) associated to Fabaceae of agricultural importance in Cerrado and Amazon-Caatinga ecotone from Brazilian Mid-North
}

\author{
Élison Fabrício Bezerra Lima ${ }^{1,2}$, Renata Chiarini Monteiro ${ }^{l}$ \& Roberto Antonio Zucchi ${ }^{1}$ \\ ${ }^{1}$ Departamento de Entomologia e Acarologia, Escola Superior de Agricultura "Luiz de Queiroz", \\ Universidade de São Paulo - USP, Av. Pádua Dias, 11, CEP 13418-900, Piracicaba, SP, Brasil. www.esalq.usp.br \\ ${ }^{2}$ Corresponding author: Élison Fabrício B. Lima, e-mail: elisonfabricio@hotmail.com
}

LIMA, E.F.B., MONTEIRO, R.C. \& ZUCCHI, R.A. Thrips species (Insecta: Thysanoptera) associated to Fabaceae of agricultural importance in Cerrado and Amazon-Caatinga ecotone from Brazilian Mid-North. Biota Neotrop. 13(2): http://www.biotaneotropica.org.br/v13n2/en/abstract?identification-key+bn03713022013

\begin{abstract}
Little is known about the Thysanoptera fauna from Brazilian Mid-North. In spite of being a region with at least three biomes and some ecotones, the studies on this insect order in the region are related to associations to a few cultivated plant species. On Fabaceae, plant family with the second largest number of records of thrips species associated in Brazil and huge economic importance for Mid-North, there are thrips records only on cowpea (Vigna unguiculata (L.) Walp.). Due to the lack of knowledge on the Thysanoptera fauna in such a diverse area and the importance of crops of this family in the region, this research aimed to survey the thrips species associated to Fabaceae of agricultural importance in areas of Cerrado and Amazon-Caatinga ecotone in Brazilian Mid-North, as well as provide basic biological information about damage and hosts. Also, comparison between the Thysanoptera fauna of fabaceous crops in the region and the rest of the Country and a key to species are presented. Thrips were collected on six fabaceous crops in four municipalities in the state of Maranhão and in one municipality in the state of Piauí. Eight thrips species were identified: Caliothrips phaseoli (Pergande, 1895), Frankliniella brevicaulis Hood, 1937, F. gardeniae Moulton, 1948, F. insularis (Franklin, 1908), F. schultzei (Trybom, 1910), F. tritici (Fitch, 1855), Haplothrips gowdeyi (Franklin, 1908) and Salpingothrips minimus Hood, 1935. Two other unidentified species were collected: Plesiothrips sp. and Scolothrips sp. Except for F. schultzei, the thrips species surveyed in Maranhão are first records in the state, and $F$. gardeniae is first record in the state of Piauí. The first records of thrips on Phaseolus lunatus L. in Brazil were established. Some species known as pests of Fabaceae mostly in southern and southeastern Brazil were not found in Mid-North. Voucher-specimens are deposited at the Entomological Collection of the Department of Entomology and Acarology, Escola Superior de Agricultura "Luiz de Queiroz", Universidade de São Paulo (ESALQ/USP).
\end{abstract}

Keywords: identification, thrips diversity, fabaceous, host association, damages.

LIMA, E.F.B., MONTEIRO, R.C. \& ZUCCHI, R.A. Espécies de tripes (Insecta: Thysanoptera) associadas a Fabaceae de importância agrícola em Cerrado e ecótono Amazônia-Caatinga do Meio-Norte Brasileiro. Biota Neotrop. 13(2): http://www.biotaneotropica.org.br/v13n2/pt/abstract?identification-key+bn03713022013

Resumo: Pouco se sabe sobre a fauna de Thysanoptera do Meio-Norte do Brasil. A despeito de ser uma região com pelo menos três biomas e alguns ecótonos, os estudos sobre essa ordem de insetos na região são relacionados a associações a poucas espécies vegetais cultivadas. Em Fabaceae, família vegetal com o segundo maior número de registros de espécies de tripes associadas no Brasil e grande importância econômica no Meio-Norte, há registros somente em feijão caupi (Vigna unguiculata (L.) Walp.). Devido à falta de dados sobre a fauna de Thysanoptera nessa área diversa e à importância de culturas dessa família na região, esta pesquisa teve como objetivo conhecer as espécies de tripes associadas a Fabaceae de importância agrícola em áreas de Cerrado e ecótono Amazônia-Caatinga no Meio-Norte do Brasil, bem como disponibilizar informações biológicas básicas sobre danos e hospedeiros. Além disso, comparações entre as faunas de Thysanoptera de fabáceas cultivadas na região e no resto do País e uma chave para as espécies são apresentadas. Os tripes foram coletados em seis espécies de Fabaceae de importância agrícola em quatro municípios do estado do Maranhão e em um município no estado do Piauí. Oito espécies de tripes foram identificadas: Caliothrips phaseoli (Pergande, 1895), Frankliniella brevicaulis Hood, 1937, F. gardeniae Moulton, 1948, F. insularis (Franklin, 1908), F. schultzei (Trybom, 1910), F. tritici (Fitch, 1855), Haplothrips gowdeyi (Franklin, 1908) e Salpingothrips minimus Hood, 1935. Duas outras espécies não identificadas foram coletadas: Plesiothrips sp. e Scolothrips sp. Exceto por F. schultzei, todas as espécies de tripes coletadas no Maranhão são registradas pela primeira vez no estado, e $F$. gardeniae é registrada pela primeira vez no estado do Piauí. Foram estabelecidos os primeiros registros de tripes em Phaseolus lunatus L. no Brasil. Algumas espécies conhecidas como pragas de Fabaceae no Brasil, principalmente no sul e sudeste, não foram encontradas no Meio-Norte. Os espécimes-testemunha estão depositados na Coleção Entomológica do Departamento de Entomologia e Acarologia da Escola Superior de Agricultura "Luiz de Queiroz", Universidade de São Paulo (ESALQ / USP).

Palavras-chave: identificação, diversidade de tripes, fabáceas, associação hospedeira, danos. 


\section{Introduction}

Although much progress has been done on Thysanoptera research in the Neotropics in the last decade (Alves-Silva \& Del-claro 2010), the scientific knowledge about the association of Thysanoptera with native or cultivated plants in the Neotropical region is practically nonentity (Pinent et al. 2005).

In Brazilian Mid-North, for example, there is a rich biodiversity in various biomes and transition areas and a large area occupied by agriculture, especially in Cerrado, but only a few thrips species are recorded from this area. Maranhão, for example, is the Brazilian state with the largest number of biomes and has more than 2.5 million hectares used by crops of agricultural importance in regional and national levels (INSTITUTO... 2009).

Fabaceae, such as soybeans (Glycine max (L.) Merr.), cowpea (Vigna unguiculata (L.) Walp.) and Lima bean (Phaseolus lunatus L.) stand out as some of the most important crops for the region. Thrips biodiversity associated to Fabaceae is expressive in Brazil. It is the plant family with the second largest number of thrips species recorded (Monteiro 2002), and at least six of them are considered pests (Monteiro et al., 1999). In spite of it, in Mid-Northern Brazil, thrips associated to economically important fabaceous are poorly known, as studies on thrips fauna in this area have been neglected. In fact, considering these crops, there are records of thrips only on cowpea (Fontes et al. 2011, Lima et al. 2013). Few surveys have been carried out and little is known about the identity and biological aspects of its thrips fauna, although damages caused by some pests in the region are already reported (Andrade Junior et al. 2002, Silva et al. 2008, Fontes et al. 2011, Lima et al. 2013).

In this paper, the first significative approach on thrips on economically important fabaceous from Brazilian Mid-North is carried out. We aimed to survey thrips species associated to Fabaceae of agricultural importance in Cerrado and Amazon-Caatinga areas in Brazilian Mid-North and to provide basic knowledge on damages and host-association of the species. Also, comparision between thrips fauna associated to Fabaceae of the region and the rest of the country and an illustrated key to facilitate further researches on thrips from this region are provided.

\section{Material and Methods}

Thrips specimens were collected on six fabaceous species of agricultural importance from several sites of the Brazilian MidNorth, in 2010 (July, August and December) and 2011 (January and July), during the period of planting and flowering in the region. The plants sampled were Arachis hypogaea L. (peanut), Cajanus cajan (L.) Millsp. (pigeon pea), Crotalaria sp. (sunn hemp), Glycine max (L.) Merr. (soybeans), Vigna unguiculata (L.) Walp. (cowpea) and Phaseolus lunatus L. (Lima bean). Flowers and leaves were manually removed and taken to the laboratory for insect screening. Collections were carried out in four important producer municipalities of the State of Maranhão, namely Balsas ( $07^{\circ} 32^{\prime} 20^{\prime}$ ' S and $46^{\circ} 03^{\prime} 10^{\prime \prime}$ W), São Raimundo das Mangabeiras ( $06^{\circ} 50^{\prime} 02^{\prime \prime} \mathrm{S}$ and $45^{\circ} 24^{\prime} 14^{\prime \prime}$ W) and Tasso Fragoso ( $08^{\circ} 24^{\prime} 09^{\prime \prime} \mathrm{S}$ and $\left.46^{\circ} 04^{\prime} 28^{\prime \prime} \mathrm{W}\right)$ within the biome Cerrado, and São Luís ( $02^{\circ} 35^{\prime} 01^{\prime \prime} \mathrm{S}$ and $\left.44^{\circ} 12^{\prime} 33^{\prime \prime} \mathrm{W}\right)$ within a transition area of Amazon-Caatinga and one in the State of Piauí - Teresina $\left(05^{\circ} 05^{\prime} 21^{\prime \prime} \mathrm{S}\right.$ and $\left.42^{\circ} 48^{\prime} 07^{\prime \prime} \mathrm{W}\right)$, within a transition area of Amazon-Caatinga. When larvae of these insects were also collected, host associations were established. For larvae identification, keys proposed by Speyer and Parr (1941), Vance (1974) and Heming (1991) were used. When failing to obtain the identification using these keys, some of the host-associations were established based on larvae collected together with adults (Pinent et al. 2005). Slide preparation methods were based on Mound \& Marullo (1996), and the voucher specimens are deposited at ESALQ/USP (Piracicaba, Brazil).

\section{Results}

Eight thrips species were identified, namely Caliothrips phaseoli (Pergande, 1895), Frankliniella brevicaulis Hood, 1937, F. gardeniae Moulton, 1948, F. insularis (Franklin, 1908), F. schultzei (Trybom, 1910), F. tritici (Fitch, 1855), Haplothrips gowdeyi (Franklin, 1908) and Salpingothrips minimus Hood, 1935 (Table 1). Besides, two not identified species were recorded, namely Plesiothrips sp. and Scolothrips sp. Except for F. schultzei, all remaining species are first recorded in the state of Maranhão, and $F$. gardeniae is the first recorded in the state of Piauí. Association between thrips and Phaseolus lunatus L. is established for the first time in Brazil. Salpingothrips minimus had already been recorded in Brazil, but there was no information on collection data (Monteiro 1999). Prior to this study, thrips species associated to fabaceous crops in this area were recorded only on cowpea (Fontes et al. 2011, Lima et al. 2013). On all fabaceous sampled, except for soybeans, seven host-associations with thrips were established (Table 1).

The specimens identified as $F$. tritici herein studied have posteroangular major pronotal setae slightly less than $1 / 2$ of the pronotal length, therefore smaller than these setae on specimens of Florida and Georgia (USA) (Figure 4H). However, these differences are intraspecific variation (Mound, personal information). In MidNorth, only yellow specimens were collected, but $F$. tritici can also be brown (Hoddle et al. 2008)

\section{Discussion}

Out of the ten thrips species previously recorded on Fabaceae crops in Brazil outside Mid-North, six are considered pests (Table 2) (Monteiro et al., 1999), but, from these, only Caliothrips phaseoli and Frankliniella schultzei were recorded in Brazilian Mid-North. Enneothrips flavens Moulton, 1941, a major peanut pest in the Brazilian southward areas, the introduced and polyphagous Thrips palmi Karny, 1925, pest of cowpea, and Echinothrips sp. and T. tabaci Lindeman, 1889, pest of soybeans, were not collected in this research. Although most of the thrips species collected in this area were already recorded in other Brazilian regions (Monteiro 1999), most of our records refer to different Fabaceae species, expanding the range of plant species associated to thrips in Brazil and showing associations different of those recorded in other Brazilian areas (Table 2).

Frankliniella schultzei (Figure 1D) is highly polyphagous and widespread (Hoddle et al. 2008) and had already been recorded in this subregion with a few comments on damage (Monteiro 1999, Fontes et al. 2011, Lima et al. 2013). In our study, it was collected on all Fabaceae sampled, and was already recorded on most of these plant species in Brazil. As for Caliothrips phaseoli, only one specimen was collected, on soybean, and it is unlike that it becomes a soybean pest in Mid-North, unless an unusual dry period occurs. Soybean is cultivated in the rainy season, an unfavorable period for thrips, as rain washes these tiny insect from the plants (Ibrahim \& Adesiyun 2010).

Major pest thrips in Brazilian southward regions may not occur in Mid-North, probably because climatic characteristics in MidNorth (higher temperatures and lower humidity) are quite different to those in southward (lower temperatures and higher humidity). The associations with plants of the other six species collected in this research - Frankliniella brevicaulis, F. gardeniae, $F$. insularis (Figure 1A), F. tritici, Haplothrips gowdeyi, Salpingothrips minimus - besides two not identified species-Scolothrips sp. and Plesiothrips sp. - are reported for the first time in Brazil (Table 1). 
Thrips on Fabaceae in Brazilian Mid-North

Table 1. Thrips association with Fabaceae of agricultural importance in Brazilian Mid-North.

\begin{tabular}{|c|c|}
\hline Thrips species & Fabaceae species \\
\hline Caliothrips phaseoli (Pergande, 1895) & Glycine max (L.) Merr. (soybean) \\
\hline Frankliniella brevicaulis Hood, 1937 & Glycine $\max$ \\
\hline F. gardeniae Moulton, 1948 & $\begin{array}{l}\text { Glycine max } \\
\text { Crotalaria sp. (sunn hemp) }\end{array}$ \\
\hline F. insularis (Franklin, 1908) & $\begin{array}{l}\text { Cajanus cajan (L.) Millsp. (pigeon pea), } \\
\text { Phaseolus lunatus L. (Lima bean)* } \\
\text { Vigna unguiculata (L.) Walp. (cowpea)* }\end{array}$ \\
\hline F. schultzei (Trybom, 1910) & $\begin{array}{l}\text { Arachis hypogaea L. (peanut)* } \\
\text { Cajanus cajan* } \\
\text { Crotalaria } \text { sp. }^{*} \\
\text { Phaseolus lunatus } \\
\text { Vigna unguiculata* }\end{array}$ \\
\hline F. tritici (Fitch, 1855) & $\begin{array}{l}\text { Arachis hypogaea } \\
\text { Glycine max } \\
\text { Cajanus cajan } \\
\text { Phaseolus lunatus* }\end{array}$ \\
\hline Haplothrips gowdeyi (Franklin, 1908) & $\begin{array}{l}\text { Crotalaria sp. } \\
\text { Glycine max }\end{array}$ \\
\hline Plesiothrips sp. & Arachis hypogaea \\
\hline Salpingothrips minimus Hood, 1935 & Glycine $\max$ \\
\hline Scolothrips sp. & Glycine $\max$ \\
\hline
\end{tabular}

* Host-associations.

Table 2. Comparison of the Thysanoptera fauna on Fabaceae of agricultural importance in Mid-North and other Brazilian regions.

\begin{tabular}{|c|c|c|}
\hline Fabaceae crops & Brazilian Mid-North & Other regions $^{1}$ \\
\hline Common bean & - & $\begin{array}{l}\text { Caliothrips phaseoli }^{+} \\
\text {Frankliniella insularis } \\
\text { F. schultzei } \\
\text { Thrips palmi }^{+}\end{array}$ \\
\hline Cowpea & $\begin{array}{l}\text { Frankliniella schultzei } \\
\text { F. brevicaulis }{ }^{2} \\
\text { F. insularis } \\
\text { F. tritici }{ }^{2} \\
\text { Haplothrips gowdeyi }{ }^{2}\end{array}$ & $\begin{array}{l}\text { Frankliniella schultzei } \\
\text { Thrips palmi }^{+}\end{array}$ \\
\hline Lima bean & $\begin{array}{l}\text { Frankliniella tritici } \\
\text { F. insularis } \\
\text { F. schultzei }\end{array}$ & - \\
\hline Peanut & $\begin{array}{l}\text { Frankliniella schultzei } \\
\text { F. tritici } \\
\text { Plesiothrips sp. }\end{array}$ & $\begin{array}{l}\text { Frankliniella schultzei } \\
\text { Enneothrips flavens }{ }^{+}\end{array}$ \\
\hline Pigeon Pea & $\begin{array}{l}\text { Frankliniella insularis } \\
\text { F. schultzei } \\
\text { F. tritici }\end{array}$ & Frankliniella insularis \\
\hline Soybeans & $\begin{array}{l}\text { Caliothrips phaseoli } \\
\text { Frankliniella brevicaulis } \\
\text { F. gardeniae } \\
\text { F. schultzei } \\
\text { Haplothrips gowdeyi } \\
\text { Scolothrips sp. }\end{array}$ & $\begin{array}{l}\text { Caliothrips phaseoli } \\
\text { Echinothrips sp. }^{+} \\
\text {Frankliniella schultzei }^{+} \\
\text {Franklinothrips vespiformis } \\
\text { Neohydatothrips flavicollis } \\
\text { Thrips tabaci }^{+}\end{array}$ \\
\hline Sunn Hemp & $\begin{array}{l}\text { Frankliniella schultzei } \\
\text { F. gardeniae } \\
\text { Haplothrips gowdeyi }\end{array}$ & $\begin{array}{l}\text { Caliothrips phaseoli } \\
\text { Enneothrips flavens } \\
\text { Frankliniella hemerocallis } \\
\text { F. schultzei }\end{array}$ \\
\hline
\end{tabular}


Lima, É.F.B. et al.

Some damages caused by thrips, mainly on flowers, were observed (Figures 1B, C), however, their economic importance need further studies in the Brazilian Mid-North. So far, thrips were known to be economically important in Mid-Northern Brazil in fabaceous crops only on cowpea, mainly during dry season (Andrade Junior et al. 2002). Their feeding on floral buds, when in high population, causes floral abortion and reduces cowpea yield.

Practical applications of the basic knowledge discussed herein can be done: Biological studies of thrips require rearing of the insects, which can be conducted using one of the host plants mentioned in this paper. As for agricultural purposes, sunn hemp is cultivated for green manure, but also grows spontaneously as weed, thus, it should be controlled due to the possibility of harboring thrips pests of other crops.

\section{Key to thrips species associated to economically important fabaceous in Brazilian Mid-North}

1. Abdominal segment $\mathrm{X}$ tubular, female without visible ovipositor (Figure 2D). Forewing without vein setae, with median constriction and series of duplicated cilia in the apical region of the posterior margin (Figure 2C). Maxillary bridge present (Figure 2A). Antennal segments III and IV with two or four simple sensilla, respectively. Head about as wide as long. Post-ocular setae with expanded apex. Basantra about as long as wide. Mesopresternum boat shaped (Figure 2B). Haplothrips gowdeyi
1'. Abdominal segment $\mathrm{X}$ conical, female with visible ovipositor (Figures 2J and 4D)

2 (1'). Head and fore femora with strong reticulation. Forewing first vein very close to the costal vein. Pronotum with reticulate sculpture (Figure 2E). Forewing with light and dark bands; first vein with incomplete row of setae (Figure 2F). Abdominal tergite VIII with complete craspedum with teeth laterally (Figure 2G). Abdominal tergites with transverse and oblique sculpture laterally ....

Caliothrips phaseoli

2'. Head and fore femora without reticulation. Forewing first vein distinct from costal vein

3 (2'). Small head with large mouth cone, extending beyond fore coxae (Figure 2H). Pronotum, trapezoidal, with two pairs of small but conspicuous posteroangular setae, with expanded apices (Figure 2I). Translucent wings. Median metanotum setae far from the anterior margin of the segment. Abdominal tergites and sternites with conspicuous craspedum . Salpingothrips minimus

3'. Head of normal size and cone mouth not extending beyond fore coxae. Pronotum without small posteroangulares setae with expanded apices
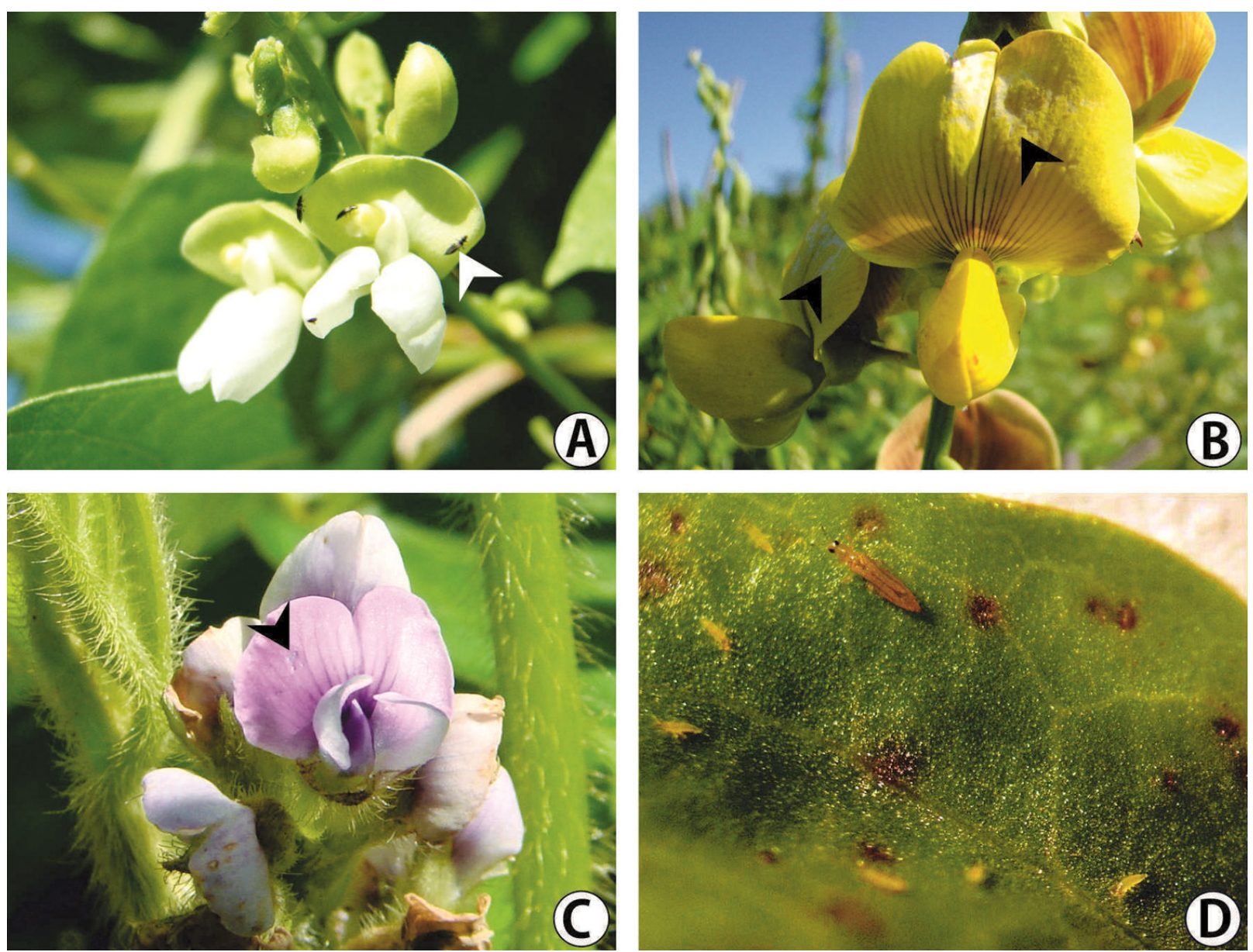

Figure 1. A. Frankliniella insularis on Lima bean flower; B. thrips damage on sunn hemp flowers; C. thrips damage on soybeans flower; D. Frankliniella schultzei (adults and imatures) on cowpea leave. 
4 (3'). Head projected in front of eyes. Antennae 7-segmented. Pronotum with two pairs of major setae. Ovipositor weakly developed (Figure 2J) Plesiothrips sp.

4'. Head not projected in front of eyes. Antennae 8-segmented. Pronotum with more pairs of major setae. Ovipositor well developed

5 (4'). Head with ocellar setae long, especially pair III (Figure 2K). Pronotum with six pairs of major setae (Figure 2L). Forewings and body color pale Scolothrips sp.

5'. Head with ocellar setae of normal size. Pronotum with five pairs of major setae. Body color variable 6

$6\left(5^{\prime}\right)$. Pedicel on antennal segment III cup-shaped (Figure 3A). Female brown. Metanotum with reticulate sculpture in the middle. Tergite VIII with posteromarginal comb complete with median teeth smaller than the lateral ones, and not scattered (Figure 4A) Frankliniella brevicaulis
6'. Antennal segment III pedicel different 7

7 (6'). Antennal segment III pedicel simple (Figures 3B and 3C) ... ..8

7'. Antennal segment III pedicel expanded (Figures 3D and 3E) ....

8 (7). Ocellar setae III close together, between the posterior ocelli and near the inner margin of the ocellar triangle (Figure 4B). Metanotum with campaniform sensilla absent (Figure 4C). Posteromarginal comb on abdominal tergite VIII incomplete, with short teeth (Figure 4D). Species either yellow or brown coloured

F. schultzei

8'. Ocellar setae III in external lateral margins of the ocellar triangle (Figure 4F). Forewings dark with basal fourth clear (Figure 4G). Posteromarginal comb on abdominal tergite VIII with moderately long teeth and variable interruption in the middle region F. insularis
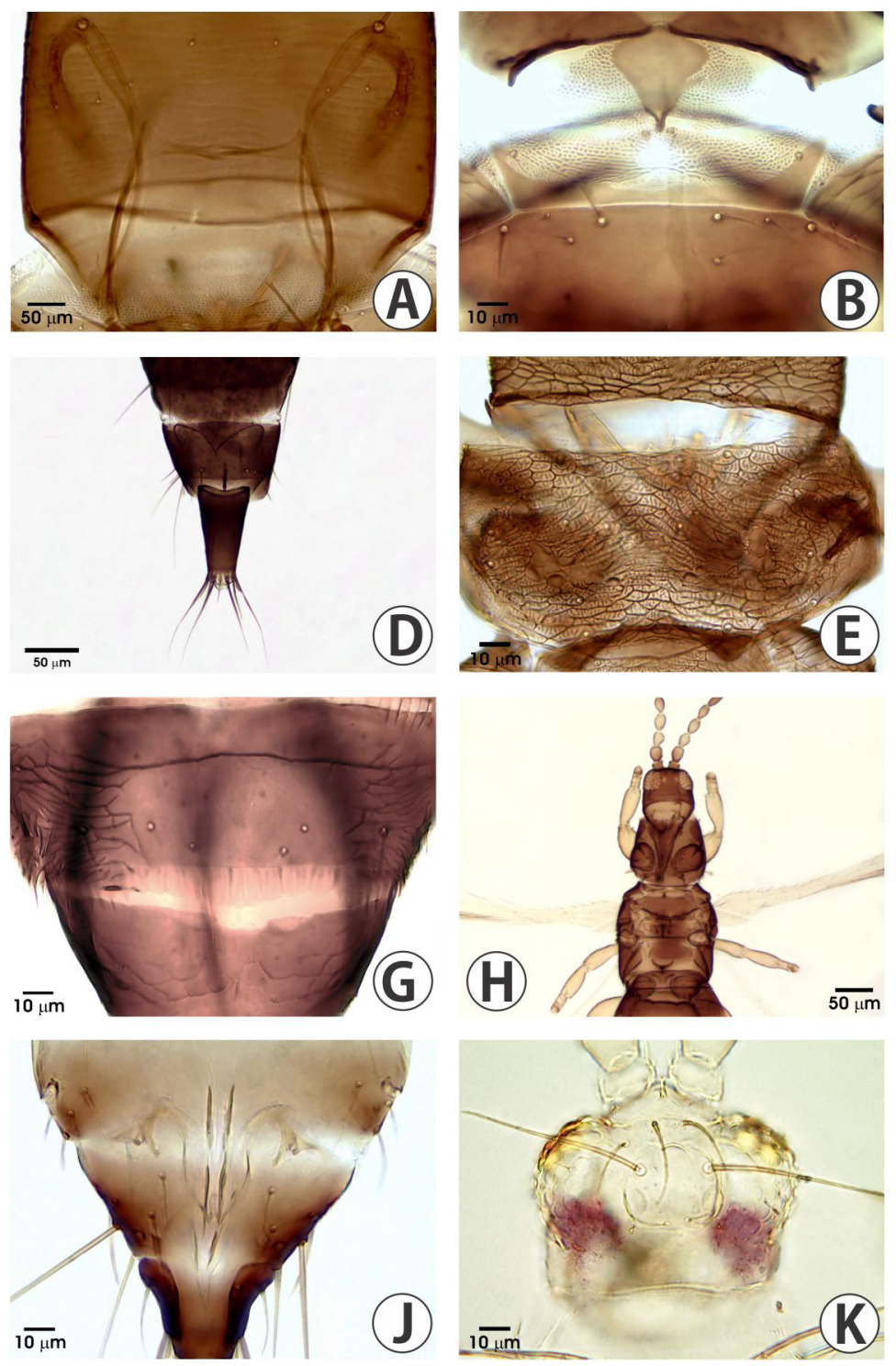
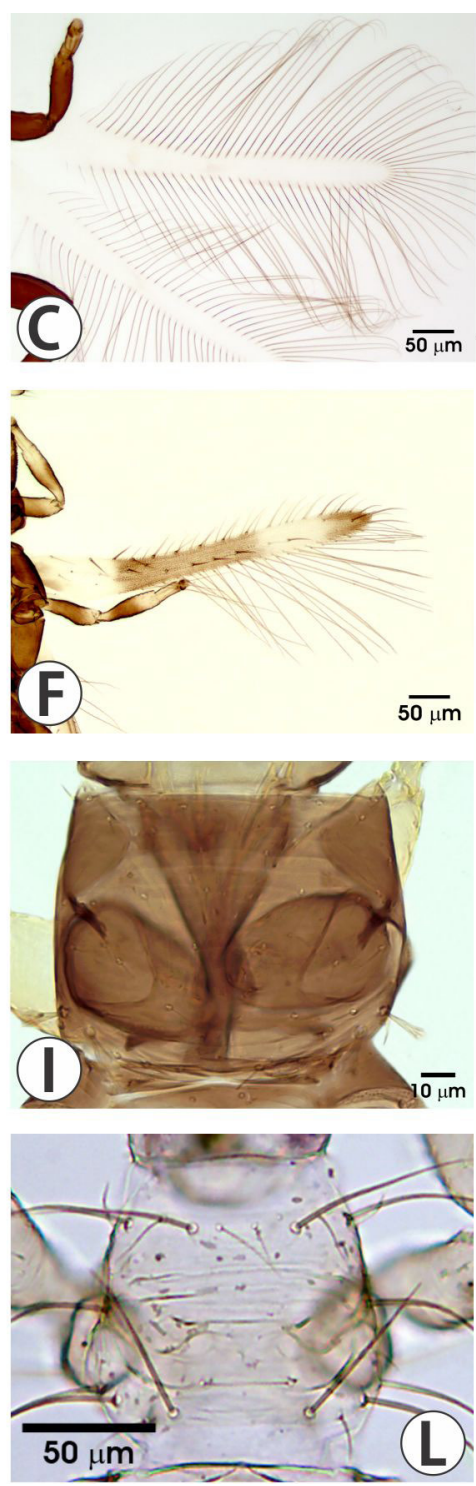

Figure 2. Haplothrips gowdeyi. A. maxyllary stylets and maxyllary bridge; B. mesopresternum boat shaped; C. right wings; D. abdominal segments VIII-X; Caliothrips phaseoli. E. pronotum; F. forewing; G. abdominal tergites VIII and IX; Salpingothrips minimus. H. head and thorax; I. pronotum; Plesiothrips sp. J. ovipositor; Scolothrips sp. K. head; L. pronotum. 
Lima, É.F.B. et al.

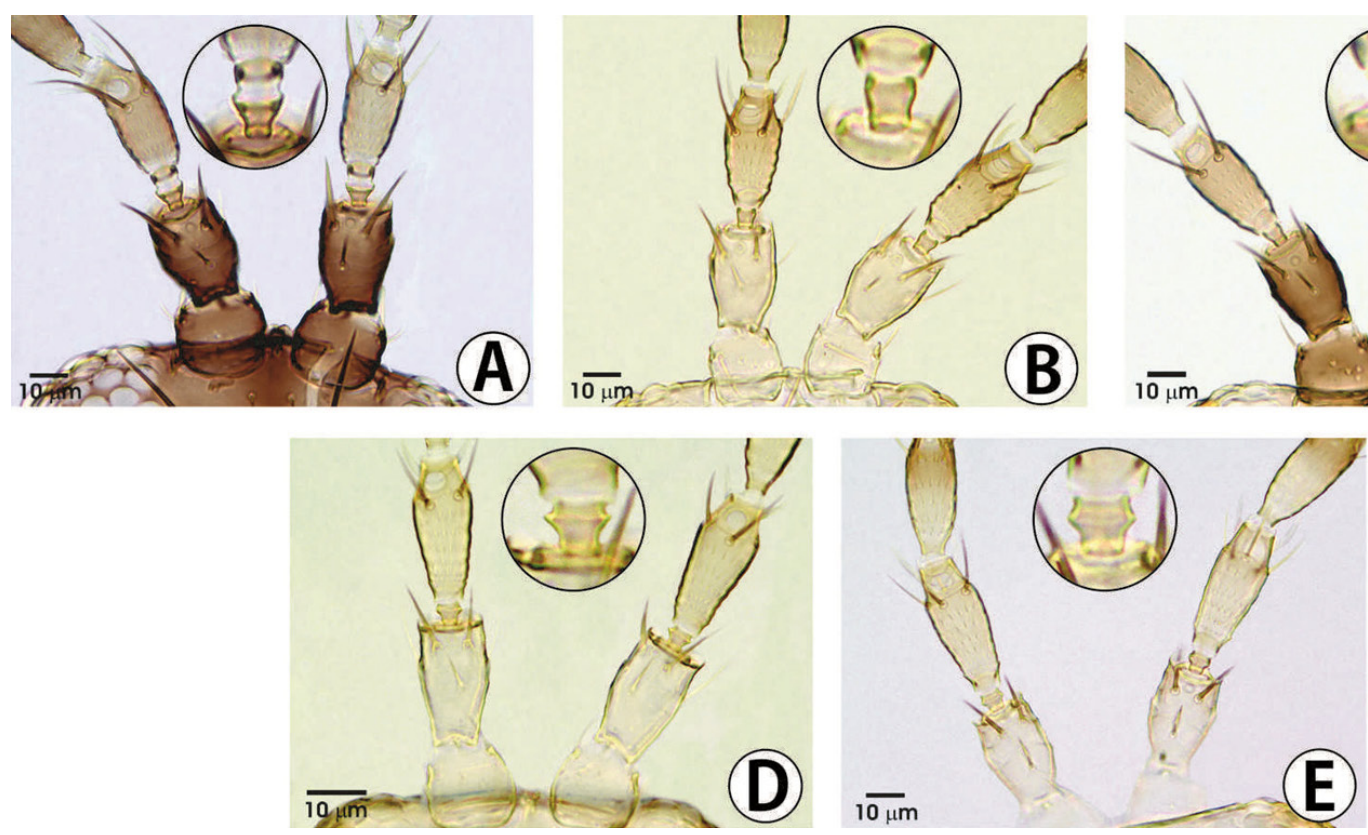

Figure 3. Part of antennae of Frankliniella species, with pedicel on segment III on detail: A. F. brevicaulis; B. F. schultzei (yellow colored); C. F. schultzei (brown colored); D. F. gardeniae; E. F. tritici.
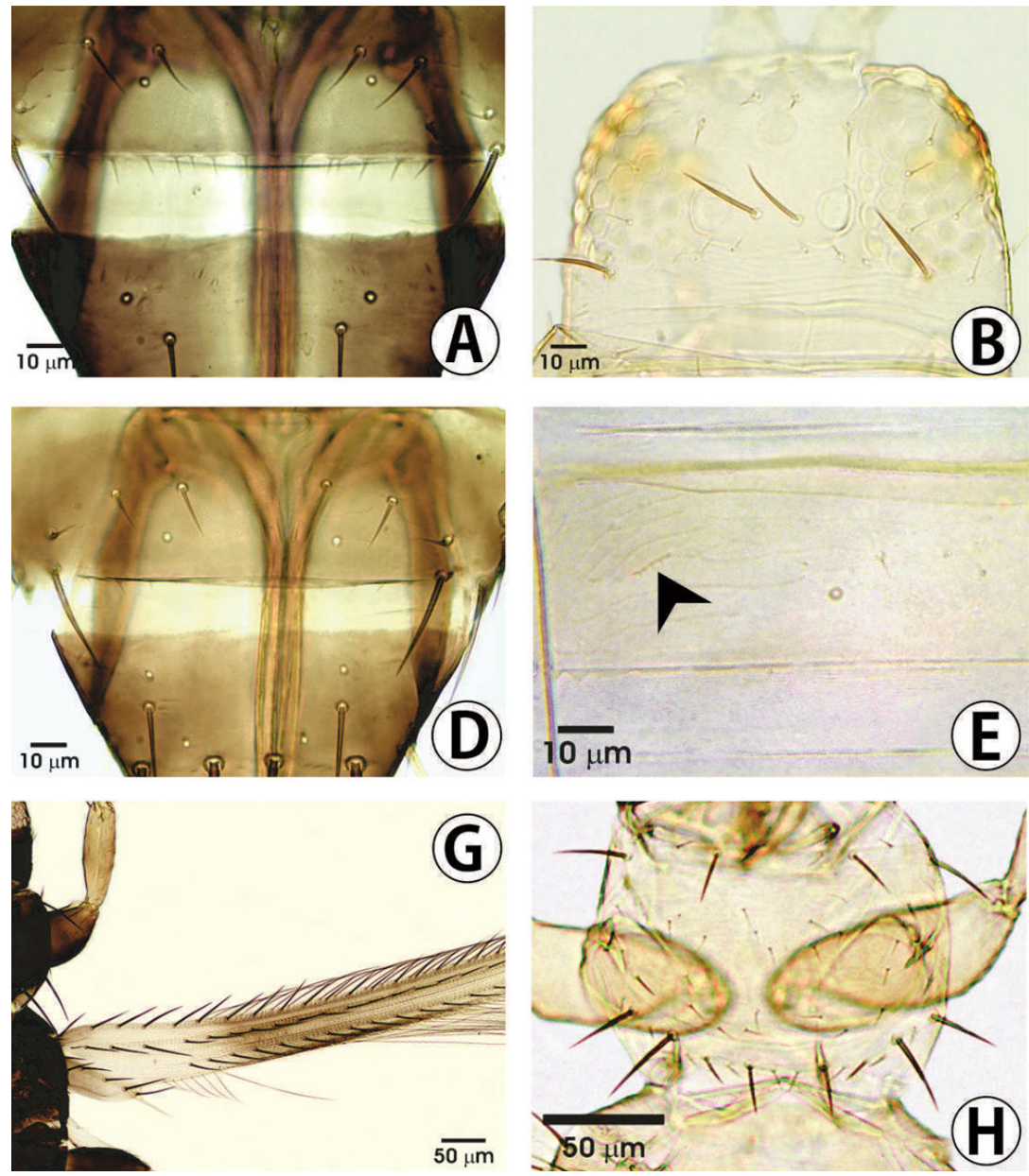
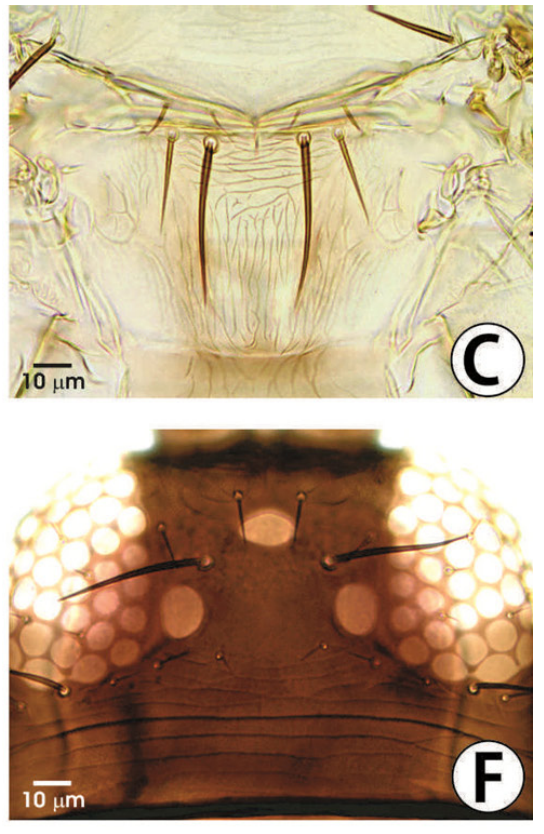

(E)

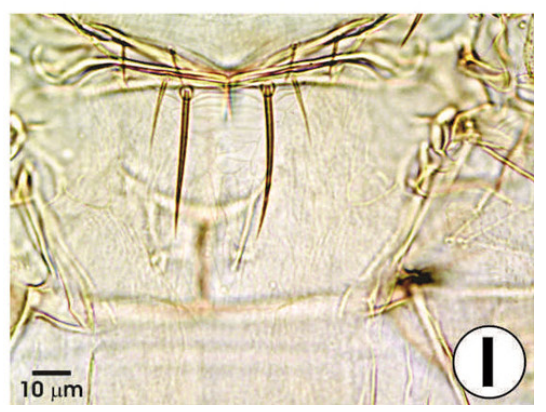

Figure 4. Frankliniella species: F. brevicaulis. A. posteromarginal comb on abdominal tergite VIII; F. schultzei (yellow colored). B. head; C. metanotum; F. schultzei (brown colored). D. posteromarginal comb on abdominal tergite VIII; F. gardeniae. E. vestigial ctenidia on abdominal tergite IV; F. insularis. F. head; G. forewing; F. tritici. H. pronotum; I. metanotum. 
9 (7'). Metanotum with transversal striate and longitudinal sculpturing in the anterior and posterior halves, respectively. Abdominal tergite IV with vestigial ctenidia (Figure 4E). Posteromarginal comb on abdominal tergite VIII complete, with moderately long teeth F. gardeniae

9'. Metanotum with small reticulation in the central part (Figure 4I). Abdominal tergite IV without ctenidia. Posteromarginal comb on abdominal tergite VIII medially interrupted with small teeth ...... F. tritici

\section{Material examined}

Caliothrips phaseoli (Pergande, 1895). Brazil. Maranhão: Balsas, on leaves of Glycine max (soybean), 18.I.2011, 1 § (E.F.B. LIMA) (ESALQ).

Frankliniella brevicaulis Hood, 1937. Brazil. Maranhão: Balsas, on leaves and flowers of Glycine max (soybean), 1 \%; São Raimundo das Mangabeiras, on leaves and flowers of G. $\max$, 19.I.2011, 1 q; Tasso Fragoso, on flowers of G. $\max , 20 . I .2011,3$ \& (E. F. B. LIMA) (ESALQ).

Frankliniella gardeniae Moulton, 1948. Brazil. Maranhão: Tasso Fragoso, flowers of Glycine $\max$ (soybean), 20.I.2011, 1 ๆ. Piauí: Teresina, on flowers of Crotalaria sp. (sunn hemp), 9.VII.2010, 11 + (E.F.B. LIMA) (ESALQ).

Frankliniella insularis (Franklin, 1908). Brazil. Maranhão: São Luís, flowers of Vigna unguiculata (cowpea), 22.I.2011, 10 ․ Piauí: Teresina, on flowers of Cajanus cajan (pigeon pea), 29.VII.2010, 1 $\rightarrow$, on flowers of Phaseolus lunatus (Lima bean), 3.VIII.2010, 35 우

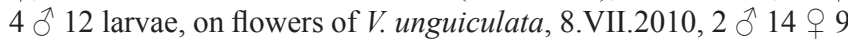
larvae (E.F.B. LIMA) (ESALQ).

Frankliniella schultzei (Trybom, 1910). Brazil. Maranhão: São Raimundo Mangabeiras, on flowers of Glycine max (soybean), 19.I.2011, 2 P ; Tasso Fragoso, on flowers of G. $\max , 20 . I .2011,6$ q. Piauí: Teresina, on flowers of Arachis hypogaea (peanut), 15.VII.2011, 13 § 22 q 14 larvae, on flowers of Cajanus cajan (pigeon pea), 29.VII.2010, 3 5 larvae, on flowers of Crotalaria sp. (sunn hemp), 8.VII.2010, 39 q 428 larvae, on flowers of Phaseolus lunatus (Lima bean), 31.VII.2010, 1 , on flowers and leaves of Vigna unguiculata (cowpea), 8.VII.2010, 27 ㅇ 9 ○े 17 larvae (E.F.B. LIMA) (ESALQ).

Frankliniella tritici (Fitch, 1855). Brazil. Maranhão: Balsas, on flowers of Glycine max (soybean), 18.I.2010, 2 ㅇ, São Luis, flowers of Arachis hypogaea (peanut), 22.VII.2011, 1 ○; São Raimundo das Mangabeiras, on flowers G. $\max , 1$ 19.I.2011, 2 P; Tasso Fragoso, on flowers of G. $\max , 20 . I .2011,4$ P. Piauí: Teresina, on flowers of Cajanus cajan (pigeon pea), 29.VII.2010, 9 , , on flowers of Phaseolus lunatus (Lima bean), 3.VII.2011, 45 o 12 larvae (E.F.B. LIMA) (ESALQ).

Haplothrips gowdeyi (Franklin, 1908). Brazil. Maranhão: Balsas, on leaves and flowers of Glycine max (soybean), 18.I.2011, 5 \&; Tasso Fragoso, on flowers of G. $\max$, 20.I.2011, 1 O; Piauí: Teresina, on leaves of Crotalaria sp. (sunn hemp), 8.VII.2010, 3 ㅇ (E.F.B. LIMA) (ESALQ).

Plesiothrips sp. Brazil. Maranhão: São Luis, on flowers of Arachis hypogaea (peanut), 22.VII.2011, 1 † (E.F.B. LIMA) (ESALQ).

Salpingothrips minimus Hood, 1935. Brazil. Maranhão: Balsas, on flowers of Glycine max, 18.VII.2010, 1 (E.F.B. LIMA) (ESALQ).
Scolothrips sp. Brazil. Maranhão: Balsas, on flowers of Glycine max, 18.VII.2010, 2 ㅇ (E.F.B. LIMA) (ESALQ).

\section{Acknowledgments}

To Dr. Laurence A. Mound (CSIRO, Australia), for the confirmation of the identification of some species; To CAPES, for the financial support given to the first author during his M.Sc. course.

\section{References}

ALVES-SILVA, E. \& DEL-CLARO, K. 2010. Thrips in the Neotropics: what do we know so far? Trends Entomol. 6:77-88.

ANDRADE JUNIOR, A.S., SANTOS, A.A., SOBRINHOS, C.A., BASTOS, E.A., MELO, F.B., VIANA, F.M.P., FREIRE FILHO, F.R., CARNEIRO, J.S., ROCHA, M.M., CARDOSO, M.J., SILVA, P.H.S. \& RIBEIRO, V.Q. 2002. Cultivo de Feijão-Caupi [Vigna unguiculata (L.) Walp.]. Embrapa Meio-Norte, Teresina, 108p.

FONTES, L.S., PINENT, S.M.J., LIMA, E.F.B. \& SUCUPIRA, I. 2011. First register of occurrence of Frankliniella schultzei (Trybom, 1910) (Thysanoptera: Thripidae) in cowpea (Vigna unguiculata (L.) Walp.) in the state of Piauí, Brazil. Braz. J. Biol. 71(4):1023-1024. http://dx.doi. org/10.1590/S1519-69842011000500023

HEMING, B.S. 1991. Order Thysanoptera. In Immature Insects v.2 (F.W. Stehr, ed.). Kendall/Hunt, Dubuque, Iowa, p.1-21.

HODDLE, M.S., MOUND, L.A. \& PARIS, D.L. 2008. Thrips of California. CBIT Publishing, Queensland.

IBRAHIM, N.D. \& ADESIYUN, A.A. 2010. Effect of rainfall in the control of onion thrips, Thrips tabaci Lindeman (Thysanoptera: Thripidae) in Sokoto, Nigeria. Agr. Biol. J. N. Am. 1(3):377-386.

INSTITUTO BRASILEIRO DE GEOGRAFIAE ESTATÍSTICA-IBGE. 2009. Levantamento sistemático da produção agrícola: 2009. http://www.ibge. gov.br/home/estatistica/indicadores/agropecuaria/lspa/default.shtm (último acesso em 11/09/2011).

LIMA, E.F.B., FONTES, L.S., PINENT, S.M.J., REIS, A.S., FREIRE FILHO, F.R. \& LOPES, A.C.A. 2013. Thrips species (Insecta: Thysanoptera) associated to Cowpea in Piauí, Brazil. Biota Neotrop. 13(1):383-386. http://dx.doi.org/10.1590/S1676-06032013000100043

MONTEIRO, R.C. 1999. Estudos taxonômicos de tripes (Thysanoptera) constatados no Brasil com ênfase no gênero Frankliniella. Tese de Doutorado, Escola Superior de Agricultura "Luiz de Queiroz", Universidade de São Paulo, Piracicaba.

MONTEIRO, R.C. 2002. The Thysanoptera fauna of Brazil. In International symposium on Thysanoptera. Australian National Insect Collection, Canberra, p.325-340.

MONTEIRO, R.C., MOUND, L.A. \& ZUCCHI, R.A. 1999. Thrips (Thysanoptera) as pests of plant production in Brazil. Rev. Bras. Entomol. 43:163-171.

MOUND, L.A. \& MARULLO, R. 1996. The Thrips of Central and South America: an introduction (Insecta: Thysanoptera). Mem. Entomol. Int. 6:1-488.

PINENT, S.M.J., ROMANOWSKI, H.P., REDAELLI, L.R. \& CAVALLERI, A. 2005. Thysanoptera: plantas visitadas e hospedeiras no Parque Estadual de Itapuã, Viamão, RS, Brasil. Iheringia, Zool. 95(1):9-16. http://dx.doi. org/10.1590/S0073-47212005000100002

SILVA, P.H.S., CASTRO, M.J.P. \& ARAÚJO, E.C.A. 2008. Tripes (Insecta: Tripidae) associados ao pinhão-manso no estado do Piauí, Brasil. Rev. Bras. Oleag. Fibr. 12(3):125-127.

SPEYER, E.R. \& PARR, W.J. 1941. The external structure of some Thysanopterous larvae. Trans. R. Ent. Soc. Lond. 91(11):559-635. http:// dx.doi.org/10.1111/j.1365-2311.1941.tb01040.x

VANCE, T.C. 1974. Larvae of the Sericothripini (Thysanoptera: Thripidae), with reference to other larvae of the Terebrantia, of Illinois. Nat. Hist. Surv. Bull. 31:145-208. 
